Diabetologia 7, 360-366 (1971)

(C) by Springer-Verlag 1971

\title{
Serum Phospholipids in Diabetic Patients with Late Manifestations
}

\author{
E. Walaas, L. Wille and H.N. Haugen \\ Institute of Medical Biochemistry, University of Oslo and University Hospital, Medical Department B, University of \\ Oslo, Norway
}

Recoived: June 22, 1971, accepted: August 3, 1971

\begin{abstract}
Summary. Serum phospholipid constituents in a selected group of hyperlipaemic diabetic patients with late manifestations have been investigated. In these patients the concentrations of serum lecithin as well as the cephalin fraction were increased. The absolute and relative increase of the cephalin fraction amounted to $3-4$ times. It is indicated that the disturbances in serum phospholipids are due to insufficient metabolic control in these patients. The possible significance of the increase of serum cephalin for the occurrence of vascular complications is discussed.
\end{abstract}

Phospholipides sériques chez des patients diabétiques ayant des manifestations tardives

Résumé. Les auteurs ont étudié les phospholipides du sérum dans un groupe sélectionné de patients diabétiques hyperlipémiques ayant des manifestations tardives. Les concentrations de lécithine sérique ainsi que la fraction céphaline étaient accrues chez ces patients. L'aug'mentation absolue et relative de la fraction céphaline atteig- nait des valeurs de 3 à 4 fois. La signification possible de cette augmentation pour les complications vasculaires est discutée.

\section{Serumphospholipide beim spät-manifesten Diabetes}

Zusammenfassung. Die Bestandteile der Serumphospholipide wurden in einer ausgewählten Gruppe von hyperlipämischen Patienten mit spät-manifestem Diabetes untersucht. Bei diesen Patienten waren sowohl die Konzentrationen des Serumlecithin als auch der Kephalinfraktion erhöht. Der absolute und relative Anstieg der Kephalinfraktion betrug das 3-4-fache. Es wird angenommen, daß die Störungen im Stoffwechsel der Serumphospholipide auf die ungenügende Stoffwechselkontrolle bei diesen Patienten zurückzuführen ist. Die mögliche Bedeutung des Anstiegs des Serumkephalin wird in Hinblick auf das Eintreten von Gefäßkomplikationen diskutiert. serum.

Key-words: Phospholipids, cephalin, insulin, diabetes,

the University Clinic, Rikshospitalet, Department of Medicine B, Oslo. They were selected being all of the juvenile type treated with insulin. A case report is given for each patient.

Case $I . K . B . f$. Age 58 y. Age at the onset of diabetes: $25 \mathrm{y}$. Duration of illness: $33 \mathrm{y}$. Weight: $90 \mathrm{~kg}$, Height: $162 \mathrm{~cm}$. The diabetes was badly regulated, and insulin 'feelings' frequently occured. A diabetic retinopathy with impaired vision in both eyes was present. The blood pressure was 260/140, being treated with methyldopa. No cardiac murmurs were heard and ictus cordis was not laterally displaced. Proteinuria and tibial oedema were found. However, the concentration of blood urea and creatinine were within normal limits. In addition, a slight diabetic neuropathy with lowered tendon reflexes and sensibility was demonstrated. The blood serum showed no opalescence, and the lipoprotein lipase activity was considered normal.

Case II. R.F.U.f. Age 44 y. Age at the onset of diabetes: $12 \mathrm{y}$. Duration of illness : $32 \mathrm{y}$. Weight: $61 \mathrm{~kg}$. Height: $169 \mathrm{~cm}$.

A positive family history of diabetes was established. The patient was amaurotic in both eyes because of a proliferative diabetic retinopathy. She was only slightly hypertensive (BP: 155/100). A rough systolic murmur all over the praecordium with an accentuated $A_{2}$ was heard. She had a necrotic ulcer on the right leg. Oedema in the lower limbs was present. No diabetic
The group of diabetic patients described in the present communication were all under observation in 
nephropathy was found. Serum albumin was low, with a concurrent increase in $A_{2}$-globulin $(1.1 \mathrm{~g} / 100 \mathrm{ml}$ ). Tendon reflexes were missing, indicating diabetic neuropathy. The blood serum showed no turbidity and the lipoprotein lipase activity was normal.

Case III. R.H.f. Age 42 y. Age at the onset of diabetes : $16 \mathrm{y}$. Duration of illness : $26 \mathrm{y}$. Weight: $45 \mathrm{~kg}$. Height: $158.5 \mathrm{~cm}$.

The regulation of the diabetes was difficult, and insulin 'feelings' frequently occurred. A diabetic retinopathy was diagnosed in 1959, and from 1963 amaurosis in the left eye was present, then progressive blindness in the right eye. No hypertension was found, for a period the patient was even orthostatic hypotensive (BP: 100/65). No cardiac murmurs were heard. A progressive nephropathy with reduced renal function was present (proteinuria, urea $149 \mathrm{mg} / 100 \mathrm{ml}$, creatinine $5.1 \mathrm{mg} / 100 \mathrm{ml}$ ) and slight hypoalbuminaemia and a slight reduction in the level of serum potassium. In addition, the patient had neuropathy at an early stage of development with reduction in the sense of vibration. The serum was without turbidity, and the lipoprotein lipase activity was normal.

Case IV.T.B.K.f. Age: $29 \mathrm{y}$. Age at the onset of diabetes: $13 \mathrm{y}$. Duration of illness: $16 \mathrm{y}$. Weight: $60 \mathrm{~kg}$. Height: $173 \mathrm{~cm}$.

A diabetic retinopathy was present, surgically treated with hypophysectomy resulting in visus $6 / 8.5$ in the left eye, enabling her to read. Obesity or hypertension were not present and there were no signs of coronary heart disease or peripheral vascular disease. Diabetic nephropathy or neuropathy could not be demonstrated, no proteinuria, normal serum creatinine and urea, all the reflexes intact. The serum was clear with normal lipoprotein lipase activity.

Case V.L.N.m. Age : 54 y. Age at the onset of diabetes: $30 \mathrm{y}$. Duration of illness : $24 \mathrm{y}$. Weight $60 \mathrm{~kg}$. Height: $172 \mathrm{~cm}$.

The diabetes was well regulated. The patient was not excessively obese, arterial hypertension was found (BP : 225/100); atherosclerotic degenerations, especially in the radial arteries were demonstrated. From May 1966 cardiac failure was successfully treated with digitalis. A rough, systolic cardiac murmur was heard, crepitations basally in both lungs, and hepatosplenomegali were found. The renal function was normal, moderate tibial oedema was present, but no proteinuria. The patient had a moderate, progressive neuropathy with cerebral and peripheral manifestations. His serum was not turbid, and the lipoprotein lipase activity was considered normal.

Case VI. K.O.f. Age: 24 y. Age at the onset of diabetes: $14 \mathrm{y}$. Duration of illness: $10 \mathrm{y}$. Weight: $62 \mathrm{~kg}$. Height: $169 \mathrm{~cm}$.

The diabetes was badly regulated. The father, brother and a paternal aunt were diabetics. The patient was slightly hypertensive. An open foramen ovale was surgically restituted in 1968 . No diabetic retinopathy was present. The renal function was normal with no proteinuria or oedema. Serum creatinine and urea values were within normal limits. No diabetic neuropathy had so far been demonstrated. No opalescence of the serum was seen, and the lipoprotein lipase was normal.

In Table 1 the patients are presented individually with special emphasis on the duration of illness and the state of complications. The metabolic control of the patients was based upon diurnal blood sugar levels, excretion of urinary sugar, changes in insulin requirement and general clinical evaluation during some weeks preceeding the examination of serum lipids. A satisfactory metabolic control had not been achieved in these patients except Case V (L.N.). It is seen that retinopathy was most common among late manifesta. tions in this group of patients.

Blood sampling. The blood samples were collected. after $14 \mathrm{~h}$ of fasting without use of anticoagulant. The samples were allowed to coagulate, chilled and centrifuged at $4^{\circ} \mathrm{C}$ for $10 \mathrm{~min}$ at $2000 \mathrm{r}$.p. m. After immediate separation the sera were kept in the cold and protected from light to avoid autoxidation, which can give an unspecific increase in the lysophospholipid compounds. The sera were investigated on the day of sampling.

Lipid extraction. A serum lipid extract was prepared according to Svennerholm ${ }^{1}$. Conical tubes with glass stoppers were used for the extraction procedure. To $6 \mathrm{ml}$ chloroform-methanol mixture $(1: 1, \mathrm{v} / \mathrm{v})$ was added $0.5 \mathrm{ml}$ serum dropwise with vigorous shaking on a Vortex mixer. The samples were left at room temperature for $30 \mathrm{~min}$ for complete precipitation of the proteins. The precipitate was packed by centrifugation at 2500 r.p.m. for 10 min. The supernatant fluid was transferred to a second conical tube, the precipitate was washed with $2 \mathrm{ml}$ chloroform-methanol $(1: 1, v / v)$ and the washing added to the supernatant fluid. Thereupon, $4 \mathrm{ml}$ chloroform and $2 \mathrm{ml}$ acid-salt solution $\left(0.1 \% \mathrm{NaCl}+0.002 \mathrm{~N} \mathrm{H}_{2} \mathrm{SO}_{4}\right)$ were added, and a vigorous shaking was performed for the phase separation. After centrifugation for $10 \mathrm{~min}$ at $2500 \mathrm{r}$. p.m., the upper aqueous-methanol phase was removed with a Pasteur pipette and suction. The walls of the tube and the surface of the chloroform layer were washed twice by the careful addition of $1 \mathrm{ml}$ washing reagent (prepared by mixing $15 \mathrm{ml}$ chloroform, $260 \mathrm{ml}$ methanol and $250 \mathrm{ml} 0.1 \% \mathrm{NaCl}$ ), which was removed. by suction. The lower chloroform phase was transferred to a $10 \mathrm{ml}$ cylinder, and adjusted to the mark with methanol. This serum-lipid extract was kept at $-18^{\circ}$ in the dark before use. Aliquots were taken for evaporation to dryness under nitrogen in a waterbath at $40-$ $50^{\circ} \mathrm{C}$, protected from light.

Thin layer chromatography. Chromatography was performed on glass plates $(200 \times 200 \mathrm{~mm})$, covered with silica gel G (E. Merck AG, Darmstadt, Germany). A slurry was made by mixing $40 \mathrm{~g}$ of silica gel $\mathrm{G}$ with $90 \mathrm{ml}$ water for neutral plates or $90 \mathrm{ml}$ of $0.005 \mathrm{M} \mathrm{Na}_{2}$

1 personal communication 
$\mathrm{CO}_{3}$-solution for basic plates. The slurry was transferred to the applicator and applied on the plates as a layer of $0.5 \mathrm{~mm}$ thickness. The plates were allowed to dry at room temperature for $1-2 \mathrm{~h}$, and were stored in a cabinet without drying agent. Before the experiment the plates were activated at $110^{\circ} \mathrm{C}$ for $1 \mathrm{~h}$.

The dried lipid extracts were redissolved in an ap. propriate volume $25-50 \mu l$ chloroform, and applied along a line $1.5 \mathrm{~cm}$ long with standardized micropipettes. Additional $25 \mu$ chloroform was used to wash the tubes and this volume was applied on the same line. Routinely, $5 \mathrm{ml}$ of the serum-lipid extract was evaporated for each application for the determination of lysolecithin ${ }^{2}$, sphingomyelin and cephalin. For convenience, the quantitative determination of the lecithin spot was performed by evaporating $1 \mathrm{ml}$ serum-lipid extract and was run on separate plates. Triplicates were run from each serum. Up to three serum-lipid extracts were follows: After moistening with a drop of water the spot could be scraped off and transferred to a Pyrex tube for ashing. A complete transfer was obtained by the use of a fitted spatula. Blanks from powder were cut from parts of the gel where no lipids had been applied. No phosphorus was found in these spots. The determination of total lipid $P$ in serum was done on $1 \mathrm{ml}$ serumlipid extract (corresponding to $0.05 \mathrm{ml}$ serum).

Phosphorus determination. The quantitative determination of the phospholipid samples was done essentially according to the method of Bartlett [2]. The digestion was performed in calibrated Pyrex tubes with $0.5 \mathrm{ml} 10 \mathrm{~N} \mathrm{H}_{2} \mathrm{SO}_{4}$. The ashing procedure was performed in a sand-bath at $180^{\circ}$ to $230^{\circ} \mathrm{C}$ for $1 \frac{1 / 2}{h}$. After cooling, three drops of $\mathrm{H}_{2} \mathrm{O}_{2}$ were added, and the tubes reheated for 15 minutes. Thereupon the walls were washed with $0.4 \mathrm{ml}$ water and the solution boiled for $15 \mathrm{~min}$. Then $3.0 \mathrm{ml}$ water, $0.4 \mathrm{ml} 2.5$ per cent ammoni-

Table 1. Characterization of the diabetic patients

\begin{tabular}{|c|c|c|c|c|c|c|}
\hline Patient & K. B. & R.F.U. & R.H. & T.B.K. & L.N. & K. O. \\
\hline Sex & $\mathrm{f}$ & $\mathrm{f}$ & $\mathrm{f}$ & $\mathrm{f}$ & $\mathrm{m}$ & $\mathrm{f}$ \\
\hline Age & 59 & 44 & 42 & 29 & 55 & 25 \\
\hline Type & juvenile & juvenile & juvenile & juvenile & juvenile & juvenile \\
\hline Duration of illness & $33 \mathrm{y}$ & $32 \mathrm{y}$ & $27 \mathrm{y}$ & $16 \mathrm{y}$ & $20 y$ & $11 \mathrm{y}$ \\
\hline $\begin{array}{l}\text { Need of insulin } \\
\text { (units) }\end{array}$ & $60 \div \mathbf{3} 6$ & $16+16$ & $36^{\nu}$ & $\begin{array}{l}12 \\
+ \text { thyroxine } \\
+ \text { cortisone }\end{array}$ & $28+12$ & $32+28$ \\
\hline Metabolic control & poor & poor & poor & poor & Good & poor \\
\hline Retinopathy & + & + & + & + & + & - \\
\hline Nephropathy & + & + & + & - & 一 & - \\
\hline Neuropathy & + & - & - & - & - & - \\
\hline Hypertension & 一 & + & + & - & + & + \\
\hline
\end{tabular}

prepared from each serum sample and pooled before the aliquots were taken for evaporation. Reference compounds ${ }^{3}$, each corresponding to $3-4 \mu \mathrm{g}$ phosphorus were dissolved in chloroform and applied on the plate, in addition to the three lines with extracts. One dimensional chromatograms were routinely developed. with chloroform-methanol-water (65:25:4 by volume). Additional runs were done according to Skipski et al. [21] in chloroform-methanol-glacial acetic acid-water $(25: 15: 4: 2)$. The running time was $1-1 \frac{1}{2} \mathrm{~h}(12 \mathrm{~cm}$ from the application spot). The plates were air dried at room temperature for $30 \mathrm{~min}$. The spots were detected with iodine vapour and encircled with a needle. According to the amount applied no spot exceeded $1.5 \times$ $1.5 \mathrm{~cm}$. The removal of the spots was performed as

2 Abbreviations used: LE: lecithin, LLe: lysolecithin, Sp: sphingomyelin, PE: phosphatidylethanolamine, LPE: lysophosphatidylethanolamine, PS: phosphatidylserin, P1: phosphatidylinositol, Ce: cephalin fraction.

3 Reference compounds: Highly purified lecithin, lysolecithin, phosphatidylethanolamine and lysophosphatidylethanolamine were available, thanks to the courtesy of Dr. E. Gjone, Rikspospitalet, Oslo. Sphingomyelin (bovine brain), Sigma 56B-0320. Phosphatidylinositol (bovine brain, Folch fraction I), Koch-Light 25388. Phosphatidylserine (bovine brain, Folch fraction III) Koch-Light 38406. um molybdate and $0.2 \mathrm{ml}$ Fiske-SubbaRow's reagent were added and the sample diluted to the $5 \mathrm{ml}$ mark. The reagents were mixed and heated for $7 \mathrm{~min}$ in a boiling water bath. After colour development the silica gel was removed by centrifugation at 2500 r.p.m. for $10 \mathrm{~min}$. Optical density was read at $830 \mathrm{~m} \mu$. An OD reading of 0.12 was given by $1 \mu \mathrm{g} P\left(\mathrm{KH}_{2} \mathrm{PO}_{4}\right)$. Recovery of lecithin standard from the plate was 99 per cent, of the cephalin fraction (phosphatidylethanolamine + phosphatidylserine) was 90 per cent. The average recovery for the serum lipid extracts amounted to 91.5 per cent, which is in good agreement with the recoveries given by Gjone and Orning [7].

The serum triglycerides were determined according to Laurell [12]. The serum cholesterol was determined by the method of Carr and Drekter [4]. Lipoprotein paper electrophoresis in albumin-containing buffer was performed according to Lees and Hatch [13].

Comments on the method. Determination of the individual phospholipids in serum under normal and pathological conditions requires careful analytical precautions to avoid nonspecific variations in the concentration of the compounds.

Blood sampling. As discussed by Vikrot [22], phospholipids may be liberated from the blood cells during 
coagulation, especially from the platelets, and bound to the clot. In the present work a substantial coagulation was present before chilling and no haemolysis occured. No counting of platelets was performed. In heparinized plasma Gjone et al. [6] found no difference in the concentration of the individual lipids compared with the values found in serum [7]. By counting the platelets [7] in heparinized plasma and citrated plasma the number of platelets did not influence the concentration of lysolecithin, lecithin and sphingomyelin, and only a slight increase in the cephalin fraction could be observed. The standardized procedure for blood sampling used in the present work, therefore, excludes the possibility that differences in cephalin fraction could depend upon the technique of blood sampling.

Extraction procedure. In the present work the precipitation of the serum proteins was done with the chloroform-methanol mixture $1: 1(\mathrm{v} / \mathrm{v})$ and the phase separation was performed with a $2: 1(\mathrm{v} / \mathrm{v})$ mixture, as commonly used. It is of interest that the values obtained for total lipid $\mathrm{P}$ and for the individual lipids in the control group (Table 1) show good correspondence with the values given by Gjone and Orning [7], in spite of different volumes and different salt concentration used.

Thin layer chromatography. With the routine procedure described, four distinct spots could be identified on the chromatograms, namely lysolecithin $\left(\mathrm{R}_{\mathrm{f}}\right.$ : $0.15 \pm 0.02)$, sphingomyelin $\left(\mathrm{R}_{\mathrm{f}}: 0.27 \pm 0.04\right)$, lecithin $\left(R_{\mathrm{f}}: 0.47 \pm 0.03\right)$ and cephalin $\left(\mathrm{R}_{\mathrm{f}}: 0.87 \pm 0.03\right)$.

As judged from reference compounds, no separation was obtained for the phosphatidylethanolamine and phosphatidylserine in the system. In separate experiments using the systems of Skipski et al. [21] complete separation of these compounds was not obtained on either neutral or basic plates. The apparent single spot with the $R_{\mathrm{f}}$-value of 0.87 is referred to as the cephalin fraction. The spot was distinct and showed a positive ninhydrin reaction. The three other spots showed a positive Dragendorf reaction [24] due to the presence of choline. These spots were all distinct without 'tailing'. No tendency for the sphingomyelin to separate into two spots was observed. The lysophosphatidylethanolamine $\left(\mathrm{R}_{\mathrm{f}}: 0.45\right)$, if present in the extract, would be included in the lecithin spot.

\section{Results}

Individual serum phospholipids in non-diabetics. The concentration of phospholipids in sera from the control group of non-diabetics is presented in Table 2. The material consists of young medical students, 20-23 years old. Included in Table 2 are the values obtained from young controls, aged 20-24 years, reported by Vikrot [22] and the controls given by Gjone and Orning [7], aged 20-40 years. These values were obtained by separation of the individual phospholipids by the method of thin layer chromatography as used in the present work. Nelson and Freeman [14] have presented a con-

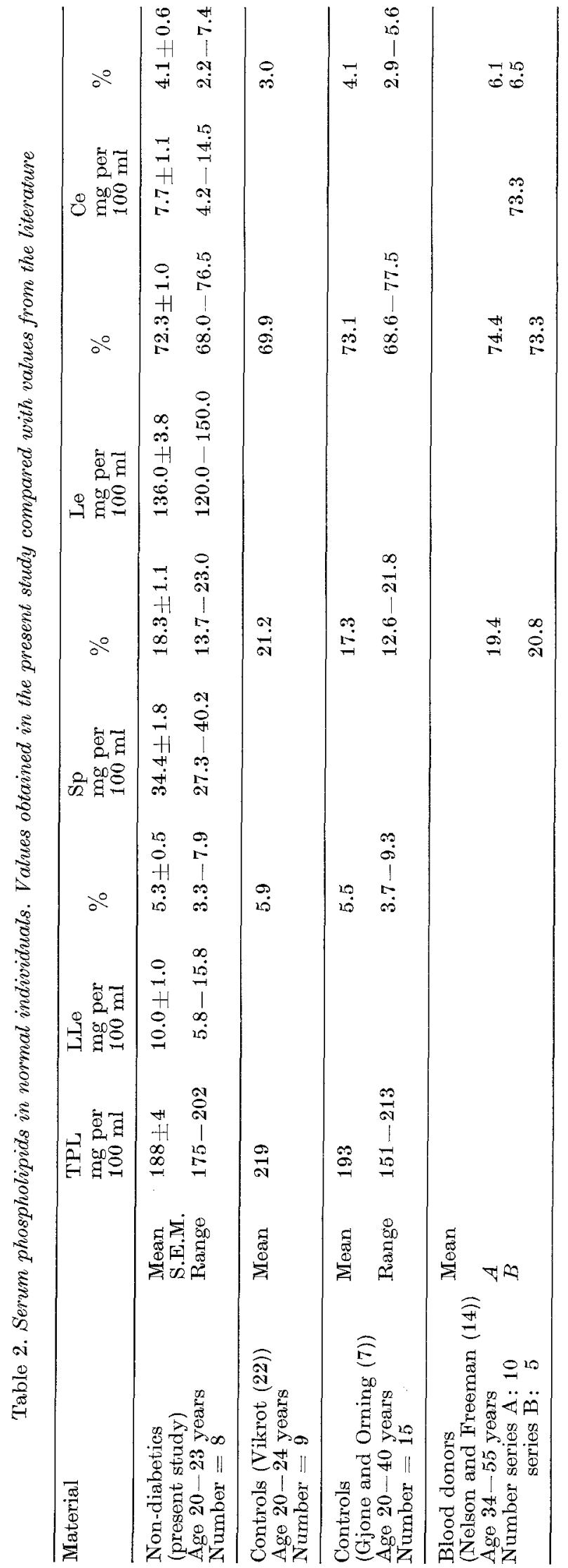


trol group of higher age, $34-55$ years, with a per cent distribution of individual phospholipids not different from the range found at younger age. The control values of the individual phospholipids in the present work correspond very well with the values given by the authors mentioned.

Individual serum phospholipids in diabetics. The level of total phospholipids and the distribution of individual phospholipid components in sera from the diabetic patients are shown in Table 3. Five of these patients had an elevated level of total phospholipids, the highest value being $321 \mathrm{mg} / 100 \mathrm{ml}$ (range of control group $175-202 \mathrm{mg} / 100 \mathrm{ml}$ ). This increase of total phospholipids in the diabetics was somewhat different from the control group. The marked increase in the cephalin fraction is reflected in a higher percentage of this group compared with the controls (mean values of diabetics 12 per cent against 4 per cent in normals). Correspondingly, the percentage distribution of lecithin is somewhat decreased (mean values in diabetics 60 per cent against 72 per cent in normals).

Determination of other lipid constituents in sera of the diabetics. The values of serum cholesterol, serum triglycerides as well as the lipoprotein pattern in the diabetic patients are also presented (Table 4 ). Four of the patients revealed some abnormalities. These patients

Table 3. Serum phospholipids in diabetic patients

\begin{tabular}{|c|c|c|c|c|c|c|c|c|c|}
\hline Patient & $\begin{array}{l}\mathrm{TPL} \\
\mathrm{mg} / 100 \mathrm{ml}\end{array}$ & $\begin{array}{l}\text { LLe } \\
1 \mathrm{mg} / 100 \mathrm{ml}\end{array}$ & $\%$ & $\begin{array}{l}\mathrm{Sp} \\
\mathrm{mg} / 100 \mathrm{ml}\end{array}$ & $\%$ & $\begin{array}{l}\mathrm{Le} \\
\mathrm{mg} / 100 \mathrm{~m}\end{array}$ & $1 \%$ & $\begin{array}{l}\mathrm{Ce} \\
\mathrm{mg} / 100 \mathrm{ml}\end{array}$ & $\%$ \\
\hline K.B. & 272 & 28.0 & 10.0 & 47.6 & 17.0 & 151 & 63.3 & 55.5 & 19.7 \\
\hline R.F. U. & 293 & 24.4 & 8.3 & 36.0 & 12.4 & 180 & 61.5 & 52.2 & 17.8 \\
\hline $\mathrm{R} . \mathrm{H}$ & 266 & 6.3 & 2.5 & 33.4 & 12.5 & 206 & 77.5 & 20.0 & 7.5 \\
\hline $\mathrm{T}, \mathrm{B}, \mathrm{K}$ & 321 & 45.0 & 14.0 & 56.6 & 17.6 & 182 & 59.6 & 37.8 & 11.8 \\
\hline $\mathrm{L} . \mathrm{N}$. & 258 & 29.8 & 11.5 & 56.8 & 22.0 & 160 & 62.0 & 11.7 & 4.5 \\
\hline $\mathrm{K} . \mathrm{O}$ & 201 & 15.2 & 7.6 & 56.8 & 28.2 & 101 & 49.8 & 28.8 & 14.4 \\
\hline Mean & 270 & 24.8 & 9.1 & 47.8 & 17.7 & 164.0 & 60.6 & 34.4 & 12.6 \\
\hline S.E.M. & $\begin{array}{r}+17 \\
\pm 17\end{array}$ & $\begin{array}{r}+5.1 \\
+5.1\end{array}$ & $\begin{array}{r}2.2 \\
+2.6\end{array}$ & $\begin{array}{r}+4.4 \\
+4\end{array}$ & $\begin{array}{r}2.4 \\
+2.4\end{array}$ & $\begin{array}{r}14.7 \\
\pm 14.0\end{array}$ & \pm 3.9 & \pm 7.1 & $\begin{array}{l} \pm 2.4 \\
\end{array}$ \\
\hline Range & $201-321$ & $6.3-45.0$ & $2.5-14.0$ & $33.4-56.8$ & $12.4-28.2$ & $101-206$ & $49.8-77.5$ & $11.7-55.5$ & $4.5-19.7$ \\
\hline$p^{a}:$ & $>0.001$ & 0.01 & 0.025 & $<0.10$ & $<0.10$ & $>0.001$ & 0.005 & 0.001 & $>0.005$ \\
\hline
\end{tabular}

a Test of significance diabetics versus controls

Table 4. Lipid constituents in sera of diabetic patients

\begin{tabular}{llll}
\hline Patient & Lipoprotein electrophoresis & $\begin{array}{l}\text { Serum- } \\
\text { cholesterol. } \\
\text { mg per } 100 \mathrm{ml}\end{array}$ & $\begin{array}{l}\text { Serum- } \\
\text { triglycerides. } \\
\text { mg per } 100 \mathrm{ml}\end{array}$ \\
\hline K.B. & hyper-beta-lipoproteinaemia & 440 & 120 \\
R.F.U. & Elevation of the pre-beta-LP fraction & 345 & 115 \\
R.H. & Hyper-pre-beta-lipoproteinaemia & 330 & 216 \\
T.B.K. & Hyper-bota-lipoproteinaemia & 400 & 128 \\
L.N. & normal & 260 & 104 \\
K.O. & normal & 260 & 83 \\
\hline
\end{tabular}

phospholipids was mainly due to an increase in the lecithin and in the cephalin fraction. The lecithin fraction was increased in four patients, the highest value being $206 \mathrm{mg} / 100 \mathrm{ml}$ (range in controls $120-150 \mathrm{mg}$ / $100 \mathrm{ml}$ ). The cephalin fraction showed a marked increase in five of these patients, the mean value being increased $4-5$ times compared with the controls. The highest value was $55 \mathrm{mg} / 100 \mathrm{ml}$ compared with a range of $4-14 \mathrm{mg} / 100 \mathrm{ml}$ in controls.

A slight increase in the lysolecithin fraction was observed in most of the patients, an observation which needs more extensive investigation. The level of sphingomyelin in serum was not significantly increased in this group of diabetics.

The percentage distribution of the individual (described in case reports as I, II, III, IV) showed a lipoprotein pattern consistent with a hyperlipaemia Type II according to the classification of Fredrickson et al. [5]. These four patients had a cholesterol level in serum ranging from $330-440 \mathrm{mg}$ per $100 \mathrm{ml}$. Patient R. H. (case report III) had also a pronounced elevated pre-beta-lipoprotein fraction. The classification of this patient will therefore be consistent also with a Type III pattern. The decision whether this patient belongs to Type II, III or IV cannot be made by simple electrophoresis and routine lipid determinations, but must be confirmed by ultracentrifugation of serum and immunological investigation as discussed by Seidel et al. [20]. The two remaining patients showed normal distribution of these lipid constituents. 


\section{Discussion}

The statement made by Fredrickson [5] that hyperbeta-lipoproteinaemia of Type II is a major causal factor in the accelerated atherosclerotic vascular disease seems well documented by many authors. In man the beta-lipoproteins are the main cholesterol and phospholipid bearing proteins. The correlation between coronary heart disease and phospholipids has been established by Nothman and Proger [15]. Their group of patients showed, in addition to hypercholesterolaemia, an increase in total phospholipids in platelet-poor plasma. An increase in the cephalin fraction was found, which amounted to 2-3 times the values found in normal controls. The cephalin fraction was also increased compared with normals when expressed as percentage of total phospholipids. Therefore these authors have called attention to the importance of this increase in the cephalin fraction in blood where arterial occlusion is present.

In the present communication the selected group of diabetic patients has shown an increase in total phospholipids, and an absolute and relative increase in the cephalin fraction. It is tempting to assume that lipoprotein particles, especially of the beta-lipoprotein type, which are rich in phospholipids, can contribute cephalins of importance for the coagulation process in blood. Several observations are in line with this hypothesis. Thus O'Brien [16] has found that phosphatidylethanolamine could substitute for platelets in the thrombin generation test, and Stypven clotting time, whereas lecithin was almost completely inactive in the coagulation of human plasma poor in platelets. Chylomicrons have been used as a source of cephalin in thrombin generation test [18], and shortening of clotting time can be observed under alimentary lipaemia. If, as suggested by Poole [17], FFA in blood also can contribute to the shortening of the clotting time, at least part of this effect can be attributed to the lipoprotein particles produced in the liver in response to FFA. Kline [11] has pointed out that even liver microsomes can have pro-coagulant activity, which when liberated to the blood can induce prothrombin activity.

The mechanism of liberation of cephalin into the blood or in the blood is poorly understood. The release of phospholipids may be related to the action of ADP [3], which is known to bring about an adhesion and aggregation of platelets [8]. Such a mechanism may be operating in disease where increase in the concentration of the cephalins in the blood is observed. Since the present work has shown an increase in total phospholipids with a relative increase in the cephalin fraction, the methylating capacity of the liver and the fat secretion mechanism are most likely disturbed under the pathological conditions described.

An important problem is whether or not the abnormalities in serum phospholipids are of primary significance for the late complications in diabetes. In studies published elsewhere [25] we have observed that diabetic patients under good clinical control have normal serum lipoprotein levels including those patients who had developed late manifestations. There was no relationship between the level of pre-betalipoproteins and diabetic retinopathy or neuropathy. Hyperlipoproteinaemia was present only in juvenile diabetics with ketoacidosis. The concept that hyperlipoproteinaemia in diabetics is related to poor control of the disease is supported by this and other investigations $[1,9,19]$. In agreement with these authors, we have not observed hyperlipoproteinaemia or an increase in serum cephalin or lecithin in maturity-onset diabetics in which there was good clinical control (unpublished observations). As mentioned previously, an appropriate metabolic control of the diabetic patients reported in the present study had not been achieved. Our investigations, therefore, indicate that the abnormalities in serum lipid constituents which have been observed occur as a secondary consequence of the diabetic metabolic disturbances.

It should be pointed out that increased serum cephalin is not a common finding in non-diabetic patients with hyperlipoproteinaemia. In such patients Vikrot et al. [23] and. Wille and Phillips [26] observed disturbances in the sphingomyelin/lecithin ratio but no increase in serum cephalin.

In conclusion, this study indicates that hyperlipoproteinaemia with an absolute and relative increase in serum cephalin occurs as a consequence of insufficient metabolic control in diabetic patients. Although our evidence indicates that these disturbances do not cause the late-developing manifestations of diabetes, these may be exaggarated when the serum cephalin level is increased.

Acknowledgements: This work was supported by a grant from the Nordic Insulin Fund. The excellent technical assistance of Mrs. Genevieve Jones and Mrs. Margrethe Tversen is greatly appreciated.

\section{References}

1. Albrink, M.J., Man, E.B.: Serum triglycerides in health and diabetes. Diabetes, 7, 194-201 (1958).

2. Bartlett, G. R.: Phosphorus assay in column chromatography. J. biol. Chem. 234, 466-468 (1959).

3. Boyd, G.S.: 'Atherosclerosis'. In: Thompson, R.H.S. and Wootton, I.D.P.: Biochemical disorders in human disease, 3. ed., p. 635-659. London: J. \& A. Churchill 1970.

4. Carr, J.J., Drekter, I.L.: Simplified rapid technique for the extraction and determination of serum cholesterol without saponification. Clin. Chem. 2, 353368 (1956).

5. Fredrickson, D.S., Levy, R.I., Lees, R.S.: Fat transport in lipoproteins - an integrated approach to mechanisms and disorders. New Engl. J. Med. 276, $32,94,148,215,273$ (1967).

6. Gjone, E., Berry, J.F., Turner, D.A.: The isolation and identification of lysolecithin from lipid extracts of normal human serum. J. Lipid Res. 1, 66-71 (1959).

7. - Orning, O.M.: Plasma phospholipids in patients 
with liver disease. A quantitative thin layer chromatographic study. Scand. J. clin. Lab. Invest. 18, 209216 (1966).

8. Gaarder, A., Jonsen, J., Laland, S., Hellem, A., Owren, P.A.: Adenosine diphosphate in red cells as a factor in the adhesiveness of human blood platelets. Nature (Lond.) 192, 531-532 (1961).

9. Hiekkala, H., Ahola, T., Akerblom, H. : Some aspects of plasma lipid and protein fractions in juvenile diabetics. Ann. Paediat. Fenn., 12, $76-82$ (1966).

10. Hovmand, L.L., Brøns, K., Gormsen, J.: Platelet phospholipids and Stypven Clotting Time. Thrombos. Diathes. haemorrh. (Stuttg.) 21, 463-471 (1969).

11. Kline, D.L.: Blood coagulation: Reactions leading to prothrombin activation. Ann. Rev. Physiol. 27, 285306 (1965).

12. Laurell, S.: A method for routine determination of plasma triglycerides. Scand. J. clin. Lab. Invest. 18, $668-672(1966)$.

13. Lees, R.S., Hatch, F.T.: Sharper separation of lipoprotein species by paper electrophoresis in albumincontaining buffer. J. Lab. clin. Med. 61 518-528 (1963).

14. Nelson, G.J., Freeman, N.K.: The phospholipid and phospholipid fatty acid composition of human serum lipoprotein fractions. J. biol. Chem. 235, 578-583 (1960).

15. Nothman, M.M., Proger, S.: Cephalins in the blood. Patients with coronary heart disease and patients with hyperlipemia. J. Amer. med. Ass. 179, 40-43 (1962).

16. O'Brien, J.R.: The similarity of the action of phosphatidylethanolamine and platelets in blood coagulation. J. clin. Path. 9, 47-51 (1956).

17. Poole, J.C.F.: The effect of certain fatty acids on the coagulation of plasma in vitro. Brit. J. exp. Path. 36, $248-260(1955)$.
18. Robinson, D.S., Poole, J.C.F.: The similar effect of chylomicra and ethanolamine phosphatide on the generation of thrombin during coagulation. Quart. J. exp. Physiol. 41, 36-50 (1956).

19. Salt, H.B., Wolff, O.H., Nestadt, A., Lloyd, J.K.: Control of lipaemia in children with diabetes mellitus. The role of insulin and the effects of a diet rich in unsaturated fatty acids. Lancet $1960 \mathrm{I}, 71-75$.

20. Seidel, D., Alaupovic, P., Furman, R.H.: A lipoprotein characterizing obstructive jaundice. 1. Method for quantitative separation and identification of lipoproteins in jaundiced subjects. J. clin. Invest. 48, $1211-1223(1969)$

21. Skipski, V.P., Peterson, R.F., Barclay, M.: Separation of phosphatidyl ethanolamine, phosphatidyl serine and other phospholipids by thin-layer chromatography. J. Lipid Res. 3, 467-470 (1962).

22. Vikrot, O.: Quantitative determination of plasma phospholipids in pregnant and non-pregnant women, with special reference to lysolecithin. Acta med. scand. 175, $443-453(1964)$.

23. - Berlin, R., Oldfelt, C.O.: Individual plasma phospholipids in hypercholesterolaemia. Acta med. scand. 189, 93-96 (1971).

24. Wagner, H., Hörhammer, L., Wolff, P.: Dünnschichtchromatographie von Phosphatiden und Glykolipiden. Biochem. Z. 334, 175-184 (1961).

25. Wille, L.E.: Pre-beta lipoproteins in clinical well controlled diabetics. In Press (1971).

26. Wille, L.E., Philips, G.B.P.: Demonstration of a novel pre-beta lipoprotein in human serum by agarose electrophoresis. In Press (1971).

Dr. E. Walaas

Institute of Medical Biochemistry

University of Oslo

Oslo, Norway 